\title{
'The Sparta and the Athens Of Our Age At Daggers Drawn': Polities, Perceptions, and Peace
}

\author{
Published in International Politics 41, no. 4 (December 2004): 582-604. \\ Copyright 2004 Palgrave Macmillan Ltd.
}

\author{
Matthew Rendall \\ School of Politics, University of Nottingham \\ University Park \\ Nottingham NG7 2RD \\ United Kingdom \\ 44-(0)115-846-6231 \\ Matthew.Rendall@nottingham.ac.uk
}

\begin{abstract}
While historically notions of democracy have varied widely, democratic peace theory has generally defined it in procedural terms. This article takes a close look at the Anglo-French confrontation of 1840. I show that while leaders on both sides were prepared to risk war to gain bargaining advantages, only the French left really wanted to fight. Why? By today's criteria, Britain was incontestably more democratic, with its monarch's powers far more restricted and its suffrage several times as large. Nevertheless, both sides considered France more democratic, with French republicans despising Britain as an aristocratic oligarchy. While Spencer Weart is right to argue that democratic republics may be hostile to oligarchic ones, they will not necessarily define each other according to modern procedural criteria. Instead, they may judge regimes by the broader social structures that shape power relationships and by outcomes, possibly explaining wars or near misses between 'democracies'.
\end{abstract}

Keywords: Democratic peace, perceptions, oligarchy; Britain; France 


\section{Introduction $^{1}$}

'[T]he only states that halloo for hostility in these days are those into which democracy has widely entered,' wrote a London Times essayist on 10 October 1840, 'restless France and self-governing America. And thus futile and false is the radical philosophy which pretends that democratic governments are a security against the costs and crimes of war.' Democratic peace theorists might well think this was the pot calling the kettle black. Was not Britain's suffrage several times as large as that of France? Was not King Louis-Philippe far more powerful than Queen Victoria?

Democracy means different things to different people, but to most democratic peace theorists it means much the same thing. Democracies have repeated competitive elections, with toleration of political opposition and peaceful transfers of power; some analysts add free speech to the list. Yet historically, definitions of democracy have varied widely. American Federalists and Republicans, Whigs and Jacksonian Democrats disagreed about what democracy meant in the eighteenth and nineteenth centuries (Owen, 1997). According to Spencer Weart (1998), republics with differing levels of suffrage have considered each other illegitimate and gone to war. 'In the nineteenth century,' Ido Oren $(1995,151)$ observes, 'democracy was associated with socialism more than with liberalism. It was understood as the rule of a particular class, the working demos.'

This article examines the Anglo-French crisis of 1840, which Christopher Layne (1997) says contradicts democratic peace theory: While the two sides never came to blows, leaders on both sides threatened the others, and the French left bellowed for war. I show that John Owen's theory, which emphasises perceptions of liberalism, accounts for much, though not all, of the evidence. Some Britons saw France as a fellow liberal state, and several officials were influenced by liberal solidarity-or hostility to conservative Russia. While through most of the crisis they failed to restrain Britain's hardline foreign minister, Lord Palmerston, at the end they forced him into concessions, possibly contributing to the peaceful outcome. The bad news is that French officials were indifferent to liberal solidarity, and the prime minister, an outspoken liberal, was 
prepared to risk war with Britain. Nor did knowledge of checks and balances and a peace party in the opponent's camp make for conciliation, as democratic peace theories often assume; instead, it encouraged both sides to hold out for a better deal. Still, no officials on either side wanted war, nor did the British public.

Much of the French left did want war, and here Weart's argument that oligarchic and democratic republics can fight provides the key. While by today's procedural criteria Britain was incontestably more representative, the French left considered it an aristocratic oligarchy. 'The old governments of monarchical Europe feared the operation of our constitutional machine,' wrote the Siècle (3 August 1840), 'they mistrust England, but they fear France. Our revolution is accomplished, while England is in the same position as the Northern Courts [Austria, Prussia and Russia]: she has yet to bring her own about.' To French republicans Britain was 'in its social constitution where we ourselves were before '89' (Le National, 13 August 1840), despite a far more limited monarch and a suffrage that was proportionally at least four times as large. The heritage of the Revolution, the dominance of the bourgeoisie and the July Monarchy's susceptibility to public pressure caused observers on both sides of the Channel to consider France the more democratic of the two states.

I begin by summarising cultural-normative theories of democratic peace, and why the 1840 crisis is suitable for testing them. I describe the development of the Anglo-French entente, the principal political factions in both states, and their perceptions of the other country, and give an overview of the crisis. Next I examine liberal solidarity in 1840, showing how both oligarchic-democratic hostility and knowledge of dovish sentiment on the other side impeded concessions. Nevertheless, in October, as fears of war grew, doves in both governments forced through a compromise - albeit one that favoured Britain. I conclude that states that seem 'liberal' or 'democratic' today might look quite different to contemporary observers. Even if they did not misperceive each other, or redefine democracy to exclude their enemies (Oren, 1995), they could adopt definitions quite different from those of the early $21^{\text {st }}$ century. In particular, radical democrats have often judged democracy not 
just in procedural terms, but by social structure and outcomes. Conceptions different from today's may explain wars or 'near misses' that have puzzled the statisticians.

\section{Cultural-normative theories of democratic peace}

'Cultural-normative' theories of democratic peace hold that just as liberal states resolve internal disputes peacefully, they do so with their foreign counterparts. Since most people value peace and these states represent their interests, liberals expect other liberal governments to resolve disputes peacefully. Respecting foreigners' right to selfdetermination, and expecting them to avoid coercion, they compromise rather than fight. People identify with states that have the institutions they want at home, and resist going to war with them, giving them the benefit of the doubt when their actions are ambiguous. In turn, they are suspicious of states they consider illiberal (Metskas, 2002; Owen, 1994, 89; 1997, 22-24, 31; Russett et al., 1993, 31-35). But if liberal states exercise restraint due to their assumptions about other states' behaviour, perceptions matter more than any objective criteria (Owen, 1994, 96-97). If one state misperceives another's regime typeor defines democracy differently_ — war remains possible

Cultural-normative theories also imply that liberal states should not threaten each other. States that externalise pacific norms should not trade threats, nor would one expect this of states that identified with one another. In case studies of US and British relations with other liberal states, Layne $(1994,1997)$ has argued that liberal states' willingness to coerce each other flouts the theory's core logic. Yet Owen $(1994,1997)$ has shown how democratic peace theory can explain two of Layne's American cases. Liberal states might not perceive each other as liberal. Moreover, even liberal states sometimes choose illiberal leaders, and these may threaten their counterparts. It is only when things escalate, says Owen, that society gets scared, and draws leaders back from the brink. This explains how militarised disputes can arise among democracies. But while liberal publics may tolerate leaders' strutting and posturing, cultural-normative theories do imply that they should not engage in or support such threats.

Both cultural-normative and structural-institutional theories predict that liberal states should expect mutual restraint and conciliation. ${ }^{2}$ While this might 
encourage them to reciprocate, it could also tempt them to press for a better deal (Risse-Kappen, 1995, 499-501). Bruce Russett (1993, 5-6) observes that in the Venezuela crisis, US President Grover Cleveland's 'actions look more like those of a poker player who expected his bluff to work, and not to be called.' In a later work, however, he and John Oneal $(2001,96)$ do not expect democratic leaders to bluff:

If even low-level disputes carry some potential to escalate into war, we predict democracies will avoid stepping onto this slippery slope with each other. Moreover, if democracies are confident that they will not go over the brink to war, the initiation of a low-level MID [militarised interstate dispute] by one democracy would recognized by another as a bluff....Insofar as normative theories of the democratic peace are correct, it would also be seen as a threat lacking legitimacy in domestic politics, where peace with other democracies is expected and desired.

As we will see, the second Syrian crisis does not bear these arguments out.

\section{Were Britain and France liberal?}

At this point the reader may be wondering if 1840 s Britain and France are suitable cases. Some theorists say that for peace to prevail among liberal states half or more of their adult populations must be allowed to vote. The logic of cultural-normative theory, however, suggests that even much more limited franchises should count if they reflect liberal ideology. Elites might well believe it acceptable to oppress certain groups - say, plebes or blacks. But so long as they consider it wrong to coerce another elite, and so long as both sides can restrain their leaders, the states should remain at peace. Consistent with this logic, Spencer Weart (1998, 12-14, 123) distinguishes between democratic republics, in which at least two-thirds of adult males can vote, and oligarchic republics, in which fewer than a third can do so. He holds that we should expect each form of republic to remain at peace with its counterparts, but that the two types may well fight each other:

The oligarchic leadership, fearing and despising its domestic outgroup, is in a sense already at war. It naturally stands ready to fight such people abroad, especially if they openly sympathize with the oppressed commoners. The democratic leaders, meanwhile, feel justified in fighting an elite who oppress 'people like us.'

Voting rights in Britain and France remained quite restricted at the time of the second Syrian crisis. For Britain, estimates range from three to ten percent (Ray, 1995, 127n16). Yet '[a]lthough the Reform Act of 1832 did not turn Britain into a 
mass popular democracy,' Layne $(1997,75)$ observes, 'public opinion--that is, the opinions of the press and the House of Commons--did affect British foreign policy.' 'Most important,' Owen $(1997,103)$ notes, 'the cabinet became responsible to Parliament rather than to the monarch.... [making] the executive...ultimately accountable to the electors, who could indirectly oust the cabinet through Parliament.' This, combined with electoral and other reforms, causes Owen to code Britain as liberal.

France's suffrage was even more limited. Only 0.5 percent of the population could vote in 1831 , rising to 0.7 percent by 1846 . Still fewer could serve in the Chamber of Deputies. The French legislature also incorporated a Chamber of Peers, whose members were appointed by the crown, but did not oppose the wishes of the executive, and rarely even of the other house. The constitution was modelled on Britain's, and incorporated limited protections for civil liberties; laws imposing censorship and proscribing associations of more than twenty persons were laxly enforced (Collingham, 1988). The French king's role is problematic. States ruled by monarchs or other un-elected officials with control over foreign policy should not count as liberal (Ray, 1995, 118; Russett et al., 1993, 15). Under France's July Monarchy, the king retained broad prerogatives: 'he declared war and made peace; he made public appointments and ordinances, proposed laws and might veto them.' (Collingham, 1988, 28.) J.-J. Chevallier (1958, 216-17, 23132) notes that "royal personalism" interfered with...the complete development of parliamentarism à l'anglaise....But it would be wrong to consider the legislative techniques of action and oversight [contrôle] then employed ineffective.'

On the whole, Britain and France seem best classified as liberal oligarchies. Both enjoyed civil liberties and representative government, but with a very restricted franchise. Britain, with a relatively toothless monarch (Layne 1997, 77) and at least four times as many eligible voters, was clearly more democratic by today's standards than France. Yet this was not the way Englishmen or Frenchmen saw it. As Henry Reeve wrote to Charles Greville (Johnson, 1924, 25): 
Since I have been in Paris I have learnt a lesson on the qualities of a democratic executive which I shall not easily forget, and every day I have some fresh instance of the tyranny of the folly of the many over the moderation and wisdom of the few. Lord Palmerston's conduct seems to me to exemplify to a most extraordinary degree the abuse of power by one man in an aristocratic state; but the wretched mistakes, doubts and pretensions of the French Government disclose all the essential weakness and worthlessness of a democratic administration.

The Examiner's (16 August 1840) correspondent in France took a similar view. 'England has two powers to deal with,' he observed, 'whose foreign policy is under not merely the control but the guidance of public opinion - these are France and the United States; and monstrously difficult it has become to deal with them.'

\section{Liberal solidarity and the first entente cordiale}

The 'first entente cordiale' followed France's July Revolution and Britain's reforms of the 1830s. In France the overthrow of the Bourbon dynasty brought to power liberal parties of the centre. While all supported constitutional monarchy, the centre-right wished to preserve the existing constitution, whereas the centre-left wanted to expand the franchise and exclude government appointees from serving in parliament. These liberals stressed the limitation of power, whether that of the king or the government. To the right of the centre parties stood supporters of the deposed Bourbon dynasty; to the left, Bonapartists and republicans. While the far left wanted the democratisation of society, only parts were committed to liberal values of toleration and conflict resolution (Chevallier, 1958, 220-22; Collingham, 1988, 135-36, 365-66; Soltau, 1931/1959, 33-34). When the crisis of 1840 erupted, Adolphe Thiers headed a cabinet of the centre-left.

\begin{tabular}{|l|l|l|l|}
\hline FAR LEFT & CENTRE-LEFT & CENTRE-RIGHT & FAR RIGHT \\
\hline $\begin{array}{l}\text { Bonapartists } \\
\text { Republicans } \\
\text { Le National }\end{array}$ & $\begin{array}{l}\text { Adolphe Thiers } \\
\text { Charles de Rémusat } \\
\text { Le Siècle }\end{array}$ & $\begin{array}{l}\text { Le Journal des } \\
\text { Débats }\end{array}$ & Bourbon legitimists \\
\hline
\end{tabular}

Table 1: French papers and politicians

French liberals felt a sense of solidarity with their British counterparts (Guyot, 1926, 35-36). Yet they were not republicans; like the Whigs, they wanted to keep the lower orders in their place. Much of Britain's attraction for the liberals was that it had a constitution but was not a democracy: in their view, its aristocracy made liberty possible 
(Jennings, 1986, 71-74; Zeldin, 1959, 48). As a journalist before the revolution, Thiers had held up British constitutionalism as a model for France. Yet as a minister he had proven willing to crack down on unrest with scant regard for civil liberties. The Duchesse de Orléans called him 'a revolutionary who truly believed himself a liberal.' (Bury and Tombs, 1986; Collingham, 1988.)

When the 1840 crisis broke out a Whig ministry was in office, headed by Lord Melbourne. Whigs and Tories dominated British politics. The Tories represented traditional landed interests, while Whig liberals favoured governmental reform and the extension of religious liberty, but by no means democracy. Radicals agitated for such causes as universal suffrage and the eight-hour day (Rubinstein, 1998).

\begin{tabular}{|l|l|l|}
\hline RADICALS & WHIGS & TORIES \\
\hline The Examiner & Lord Clarendon & Lord Aberdeen \\
& Lord Holland & Sir Robert Peel \\
& Lord Melbourne & Duke of Wellington \\
& Lord Palmerston & The Times \\
& Lord John Russell & \\
& The Globe and Traveller & \\
& The Morning Chronicle & \\
\hline
\end{tabular}

Table 2: British papers and politicians

British liberals, including Palmerston, welcomed France's revolution of 1830, praising its moderation in comparison with the French Revolution, and hoping that it would catalyse reform in Britain. Some called the king and his family 'French Whigs.' Conservatives, in contrast, feared that the revolution would strengthen British reform (Guyot, 1926, 39-41; Mitchell, 1997, 200; Webster, 1951, 1:79-80). As foreign minister, Palmerston echoed liberal views, writing of his 'instinctive contempt' for the eastern autocracies, while calling 'Constitutional States...the natural Allies of this country.' In 1832 he claimed that such states were 'less likely to go to war than despotic governments because money will not be voted lightly,' and predicted that a liberal alliance including France would balance 'the unholy allies in the East' (Bourne, 1982). Melbourne, despite his scepticism about political reform and hostility to popular politics, also sympathised with the French as a fellow liberal power (Mitchell, 1997). Yet Palmerston, Kenneth 
Bourne $(1982,349,630)$ observes, 'was very much inclined to think that a France of any sort was England's natural and permanent enemy.' By the late stages of the Syrian crisis

so disillusioned was he with the Bourgeois Monarchy that he professed to think war was, on some future occasion, quite inevitable.

'If we carry our point which I am now convinced we shall,' he wrote...'we shall read France quietly a lesson that will be useful to her for three or four years to come. I cannot hope that anything short of a good physical thrashing will make an impression much longer than that.'

Both Whigs and Tories took a dim view of republicanism, considering it reckless and belligerent. French republicans reciprocated their disdain. Like their American counterparts (Owen, 1997), the radicals saw Britain 'as the land of inequality, aristocracy, privilege and oligarchy.' (Jennings, 1986, 80.) In the course of the 1830 s, they came to consider bourgeois liberals as much their enemies as pro-Bourbon conservatives. While French liberals identified with the Whigs, the republicans despised them. To them, Britain stood not for democracy, but for the bourgeois constitutionalist ideal of their foes the liberals, and the two systems were in competition throughout Europe. Liberal efforts to align France with Britain were thus deeply suspect, a betrayal of France's role in the revolutionary vanguard, and an effort 'to import to the country of the Revolution the bourgeois model of the United Kingdom.' (Darriulat, 2001, 57-60.)

British Whigs, then, sympathised with France's liberal oligarchs, but had no time for its largely disfranchised left. France's governing parties admired Britain's constitutional—but by no means democratic — political system. In contrast, French radicals considered British constitutionalism not a model but a threat. This explains why in 1840 it was the left that bayed for English blood.

\section{The Anglo-French crisis of 1840}

Since the early 1830s Mehemet Ali, the Viceroy of Egypt, had wrested growing power and independence from his Ottoman overlords. In 1832 he gained control of Syria. The Sultan unwisely tried to take it back in 1839 and suffered a disastrous defeat. The great powers intervened to put Mehemet back in his box, but France, more sympathetic than the other powers to the Viceroy, opposed the use of force. On 15 July 1840 Austria, 
Britain, Prussia and Russia concluded a convention requiring Egypt to withdraw from northern Syria and envisioning coercion if it did not.

News of the convention prompted an outcry in France, with calls for war against both the Continent and 'perfidious Albion.' (Thureau-Dangin, 1884-92, 4:232-35.) Neither the king nor Thiers wanted war, but they talked tough and began military preparations. (Allison, 1926, 284; Bury and Tombs, 1986, 70-72). French society was still more bellicose. While most threats were aimed at the continental states, the public showed much hostility toward Britain (Guyot, 1926, 202-3; Thureau-Dangin, 1884-92, 4:277-82). Though the French parliament was out of session when the July convention became known, deputies announced their desire for a military build-up (Raikes, 1858, 2:214; Guizot, 1858-67, 5:250). 'In 1840, to the imprudence of the press, the tribune would have added its own,' the interior minister, Charles de Rémusat (1958-67, 3:453), later wrote, 'and in this first explosion of public opinion, my conviction was that to convene the Chambers was to march toward war.' Thiers evidently felt under domestic pressure to be firm, as did the king (Barante, 1890-1901, 6:467; Dosne, 1928, 1:202, 212; Thureau-Dangin, 1884-92, 4:243n2). If Thiers and Louis-Philippe had wished to take the country into war, they could have cooked up a pretext and won the country's roaring support. By fall, however, divisions opened up within the French cabinet, with several members calling for a softer line. The chief division was between the cabinet and the king. Though he supported Thiers' sabre-rattling so long as he felt sure it would not mean war, Louis-Philippe did not consider Egyptian rule in Syria worth fighting for (Collingham, 1988, 233; Guizot, 1858-67, 5:265, 384-85).

Similar divisions opened up in Britain. Much of Palmerston's support came from Conservatives, including Aberdeen, Peel and — with misgivings-Wellington. Rightwing Tories welcomed the rift, while centrist Tories regretted it but supported intervention in Syria. British radicals opposed the government. Much of public opinion and the press backed Palmerston (Guichen, 1921, 339, 345; Hall, 1912, 281; Hasenclever, 1914, 190; Melbourne, 1889, 461; Webster, 1951, 2:719; cf. Guyot, 1926, 192). Yet the foreign 
secretary faced increasing opposition in his own cabinet. Lord John Russell grew anxious, and pressed for an overture to France (Webster, 1951, 2:700, 713).

Meanwhile Britain and Turkey invaded Syria, scoring striking successes. On 14 September Turkey proclaimed Mehemet Ali deposed as pasha. War fever had been cooling in France, but these events provoked a new spasm of rage, with lines forming outside the recruitment offices (Thureau-Dangin, 1884-92: 4:300-1). War fever was marked among radical agitators and some deputies, and most of the press, especially on the left, called for a tough line (Raikes, 1858, 237; Thureau-Dangin, 1884-92, 4:305, 325, 328, 346). 'Some of the Paris mob cry out, "Guerre aux Anglais! ils ont pris notre Beyrout!” reported Thomas Raikes (1861, 162-63), 'which, I believe, they suppose to be a town on the coast of Normandy.' In contrast, conservatives who had supported the government, alarmed by the agitation, now turned against it (Thureau-Dangin, 1884-92, 4:303, 339-40; Tudesq, 1964, 1:494-511). Some expected the French parliament to seek peace when it was convoked, while others expected it to take a hard line (Bury and Tombs, 1986, 74-75; Reeve, 1898, 1:123-25). Across the Channel, Clarendon, the Lord Privy Seal, worried that without British concessions Louis-Philippe could be at the mercy of parliamentary hardliners, but Palmerston wrote that he had heard 'that the [French] deputies were coming up embued with the spirit of peace, and that has probably had some share in bringing about the discomfiture of Thiers.' (Russell, 1925: 1:24-27; Bulwer, 1870-74: $2: 345$.)

When the French cabinet voted to convene parliament, send the fleet to Alexandria and to send a protest to the other powers, Louis-Philippe balked, and the cabinet resigned. Eventually they struck a deal and returned. The fleet was to come back to Toulon and parliament would be convoked. France sent a note on 8 October to the other powers indicating that Paris would not go to war over Syria, but could not consent to the pasha's overthrow from outside. At first, by insisting on these terms, France was risking war, but before the note was sent Austria and Britain gave assurances that they would not depose the pasha (Bury and Tombs, 1986, 74-75, Rémusat, 1958-67, 3:47677). 
By mid-October, Thiers was angling for a compromise that would save part of Syria for the pasha, while at the same time warning of dangerous consequences if London refused to bend (Bury and Tombs, 1986, 75; Correspondence, 1841, 2:313). According to Thiers' mother-in-law, the king resisted the prime minister's demands to continue the military build-up. 'When I armed, I hoped to intimidate England,' he said, 'but today I see that my armaments have not produced this effect on Lord Palmerston. I believe, on the contrary, that he wants war. My role in that case is to take a new tack, to halt my armaments, for, I say again, I do not want war at any price.' He would even give up Alsatia 'rather than fight a war that would lose us all [our provinces].' Thiers argued that he did not want war, either, but that a continued build-up would gain concessions. France's tough line, he asserted, was already encouraging flexibility among the powers (Dosne, 1928, 214-16).

Maybe Thiers was right. In the second half of August a struggle began in the British cabinet, with Lords Russell, Holland and Clarendon pressing for a more conciliatory policy. Palmerston agreed to make overtures to France, but dragged his feet when it came time to carry them out. Nonetheless the cabinet forced him to send a conciliatory statement (which he sought to dilute) to Paris on 6 October and to inform the French eight days later that Britain would support Mehemet Ali's reinstatement in Egypt (Bourne, 1982, 597-611). On 16 October, Queen Victoria (1907, 1:306) wrote to King Leopold of Belgium that 'if France, upon this, were to make some sort of advance, and were to cease arming, I think all would do; for you see, if France goes on arming, we shall hardly be justified in not doing the same, and that would be very bad. Couldn't you suggest this to the King and Thiers, as of yourself?' Shortly afterward, Melbourne wrote to Leopold that if France continued its military build-up, he would summon Parliament. According to an Austrian report, he wrote, 'I will lay before it the conduct of France, ask for supplies in order to increase our fleets. I will take care that they shall be placed upon the largest footing,--this is in a word, War, Sir.' The Belgians, as expected, conveyed Melbourne's letter to Louis-Philippe, and the two letters apparently encouraged LouisPhilippe to oust Thiers from office (Bury and Tombs, 1986, 262n65; Webster, 1951, 
2:722-23). When an assassination attempt against the king produced a reaction in favour of peace, he had a showdown with the cabinet and dissolved it (Thureau-Dangin, 188492, 4:343-47). But had liberal norms made any difference?

\section{Liberal solidarity and the crisis of 1840}

Cultural-normative theory claims that ideological solidarity prevents liberals from going to war with one another. Most British doves during the crisis - in and out of government - were leftwing Whigs or radicals, with sympathy for France strongest on the left end of the political spectrum. But it was French radicals who really wanted war. France's government sought to preserve peace but extract concessions, with the more leftwing members of the cabinet seemingly the least inclined to compromise (Reeve, 1898, 1:125). At first glance, this seems to belie democratic peace theory: 'the liberal elements pushing France to war...had to be restrained by the most illiberal component of the French domestic political structure, the monarch.' (Layne, 1997, 90.) Yet the pieces of the puzzle fall into place when one recognises that in the eyes of both countries, Britain lay to France's right. It was French conservatives who most openly opposed war, while the left considered Britain a tyrannical oligarchy. Many of the British, in turn, found France alarmingly democratic — that is, ruled by the mob.

For the moderate-conservative Journal des Débats (30, 31 July 1840), Britain and France were the freest states in Europe, and their friendship a bulwark against Russia. The Débats wrote (29 August 1840) that 'the influential, rich and enlightened part of the [British] nation rejects, with at least as much energy as the generality of the masses, the idea of a war with France.' 'In a constitutional country, such as England,' it argued on 28/29 July 1840 ,

a minister's whim is nothing; the will of the nation is everything....Lord Palmerston will not touch off war; he will not awaken the old antipathy that lives on in his heart, but which twentyfive years of peace, progress of civilisation and conformity of institutions have stifled in the hearts of all enlightened Englishmen....So long as a solemn vote does not set us straight, we shall persist in believing that England and its Parliament will shore up the peace.... 
Though it supported Thiers' military preparations, the Débats repeatedly expressed its hopes for peace.

The centre-left Siècle also asked whether the treaty reflected the will of the British nation or Palmerston's own leanings, and hoped that internal pressure would bring the foreign secretary to heel. It expressed dismay that a country it had considered 'free and enlightened' should have sided with Europe's absolute monarchies against France (28 July, 7 August 1840). But especially as the crisis progressed, the Siècle also expressed doubts that the decision for war was in the people's hands (5 October 1840). In contrast to France, Britain was a country of 'proletarians, interlopers [étrangers] on a soil enfeoffed to the aristocracy,' which in concluding the treaty had sought ' $[\mathrm{t}] \mathrm{o}$ defend the aristocratic principle attacked by France' by distracting the people from internal matters (3, 19 August, 13 October 1840). While the Siècle deplored war 'in the heart of civilised Europe, among free nations - or at least enlightened ones' (6 October 1840), it took a strong line against concessions and held that the possibility must nevertheless be faced.

The republican National had never considered Britain free or enlightened in the first place. In its view, the entente had served to strengthen undemocratic tendencies at home. If the Chamber of Deputies was a rich man's club, French democracy was still a paragon next to Britain's, whose people was 'crushed beneath the double aristocracy of the lords and of the church...' (2, 6 August, 14 October 1840.) Even before the crisis, the paper had portrayed Britain as less democratic than France (Darriulat, 2001, 88; Mitchell, $1997,29,204,324 n 125)$. Now it argued that while '[a] war... would be applauded by the parliament, and the electoral fraction that chooses it,' the Whigs belonged to the same oligarchy as the Tories, while the British people groaned under 'the old feudal structure that still weighs upon the soil of Great Britain.' France was 'the palladium of European democracy' and '[s]ince our July revolution, the English people has grown accustomed to consider France the glorious sanctuary of European liberty.' If radicals ever came to power in Britain and France, perpetual peace would ensue between them. But Palmerston, not the people, held the reins of power, and the government was likely to succeed in 
dragging the nation into battle. $(13,14,18,19,31$ August, 28 September, 19 October 1840.) This did not faze the National, which demanded war from the outset.

Conversely, in Britain it was the left end of the political spectrum that favoured a softer line. Some historians have attributed the sympathy of certain Whigs, particularly John Russell, for France during the crisis to liberal solidarity, but with the exception of Lord Holland (Mitchell, 1980) and perhaps Melbourne, there is little to show this. In fact, Russell's most recent biographer describes him as '[f]ar less pro-French than most Whigs.' (Scherer, 1999, 121.) Russophobia may have mattered more. Holland correctly suspected a Russian ruse to drive a rift between the Western powers, and some newspapers warned that Russia stood to gain (Guichen, 1921, 345, 381; Russell, 1925, 1:19). According to L. G. Mitchell (1997, 203), Melbourne was also distressed to have abandoned liberal France for an entente with the autocratic northern courts, and this among other factors led him to press Palmerston to compromise. Conversely, the Tory Aberdeen supported Palmerston in hopes of a rupture with leftwing France and a rapprochement with the three conservative powers (Bourne, 1982, 626). Liberal ideology may not have been at the front of most British officials' minds during the crisis, but as Layne $(1997,75)$ concedes, it played some role in motivating the doves.

\section{Was the other side seen as peace-loving?}

Cultural-normative theory also holds that liberal states show restraint toward fellow liberals in the expectation that it will be reciprocated. Yet the British did not see French public opinion as a force for restraint. On the contrary, hardliners as well as softliners thought it might push the government into war (Bartlett, 1963, 143; Correspondence, 1841, 2:267; Macaulay, 1976, 3:339; Russell, 1925, 1:27). It was precisely France's 'democratic' elements that Whig and Tory newspapers found threatening, and they hoped that the propertied classes would restrain them.

On 12 October Melbourne wrote that he and Russell wanted to end the crisis swiftly in part because they feared public pressure would drive France to use force (Victoria, 1907, 1:303). He was anxious to help Louis-Philippe regain control over Thiers 
and the press (Mitchell, 1997, 204). '[I]t was well said by Mr. Halford the other day at Leicester,' Melbourne $(1889,478)$ wrote in September,

that the real danger of the interruption of peace arises from the unquiet and aggressive character of the people of France, and if this be at all encouraged by success and by our yielding, though we may stave off war at present, we shall only render it more certain within a short time.

The following month he remarked that "with a nation so irritable as the French, and with the Constitution which they have and which they are unused to exercise, it is impossible to feel secure for a moment.' (Victoria, 1907, 1:301.) Russell believed the French king was under domestic pressure to stand firm, and warned that Britain could play into the hands of his far right or far left opponents (Public Record Office, London, 30/22/3E). '[I]f war does break out,' wrote Henry Reeve (Johnson, 1924, 29),

it will be because the cursed democratic element, represented by the Press, forces the hands of the Ministers and overrules their deliberations....I have seen notes from Thiers to one of [the editors], demanding and entreating them not to involve the Government in such inextricable embarrassment.

British newspapers took a similar view. Like $19^{\text {th }}$ century American liberals (Oren, 1995, 151), the Tory Times (16 October 1840) drew a distinction between orderly constitutional government and 'the recognized despotism of democracy.' Certainly it would be a tragedy if it came to blows between Europe's great constitutional states. A letter-writer warned that an Anglo-French quarrel would play into the hands of Russia:

Does any one doubt that England, united with France, is in the full exercise of the greatest moral and political power ever wielded by a free people?....The first altercation is no fit ground of divorce from such an union; nor is it to be endured that the great aristocratic and the great democratic states of modern history, the Sparta and the Athens of our age, should be at daggers drawn, that Philip of Macedon may be aggrandized.

But far from being a valuable restraint, the French parliament posed a danger: '[T]he convocation of the [French] Chambers, the vehement outbreak of Parliamentary excitement, and the public discussion of the question at this moment, must greatly diminish the hope of diplomatic adjustment, and almost infallibly lead to the last and worst consequences.' (8,10 October 1840.) An essayist expressed the hope (10 October 1840) that the French king could impart his principled restraint to 'the better portion of the French poople [sic],' leading to an amicable solution: 
Should this desirable event be realized, it will afford an important illustration of the advantages derived to great nations from the check of monarchical institutions upon popular excitement. For the hankering after war in modern Europe is no longer with kings, but with democracies. The irritable, the rash, the fierce, the blind, and the covetous passions which prompt to war, and which in former times the people had no license to express but on the signal of their rulers, are now almost wholly of popular growth; and every brawler is sensitive about the national honour, too often in the ratio of his callousness about his own.

Peace, in the Times' view (26 September 1840), was characteristic of constitutional states, whose voters had a material stake in it. 'The diffusion of property and the love of material enjoyment,' it observed, 'are two of the characteristics of democratic communities, and these are...two main causes of a reluctance to engage in hostilities.' Yet there was democracy, and then there was democracy. The newspaper bore the French people no hostility-'except that ruffian portion who look to the storm which now lowers over Europe for the bolt which is to lay their own existing institutions low, and to give the signal for recommencing the work of democratic havoc in Europe.'

The Times, though a Tory paper, was more inclined to favour concessions than the Whig Morning Chronicle and Globe and Traveller. Both hoped that France's people and parliament would prove a force for restraint. But the Chronicle (5, 8 October 1840), like the Times, pinned its hopes on the propertied classes, whom the Globe's Paris correspondent also considered the bulwark of peace, because of their enlightenment, their fear of domestic turmoil, and because they had something to lose (12 September, 5, 7, 19 October 1840). In its 24 August leader the Globe quoted a passage from the Spectator that could have come from Barrington Moore:

In both countries the elective franchise is to all practical purposes restricted to the class of capitalists. In France, there is no admixture of a privileged aristocracy among this class; in England, the aristocracy is still highly influential. But the effect of this admixture, in so far as the present inquiry is concerned, is almost neutralised by the business habits and mercantile mode of viewing affairs contracted by our English aristocracy. The dominant power in last resort, in both countries, is a class the members of which are either possessed of large fortunes or in the course of acquiring them by the use of credit or capital - a class morbidly averse to any disturbances which interfere with its enjoyments or derange its calculations of gain.

'The Spectator intends sarcasm on the French and English governments,' added the Globe, '...and yet he has said more in their favour, on the point most important to the 
progress of civilisation (the disposition, namely, to preserve peace), than could be said of any pure democracy that ever existed.' While the Chronicle hoped for a reaction against 'the democratic party' among 'the more respectable citizens,' (12, 15 October 1840) the Globe's correspondent briefly feared (6 October 1840) that the government might 'give way to the democratic torrent.'

Though the leftwing Examiner deplored (2 August 1840) 'even the risking of a breach between the only two thoroughly liberal and constitutional countries in Europe,' at first it put the blame on France and supported the government. While at times the paper's foreign correspondent hoped that French sentiment was turning against war (30 August 1840), he blamed popular pressure for the crisis (23 August 1840). Warlike passions had 'corrupted the [French] Liberals', who made up the backbone of the war party, and 'the public has no organ, and the country no opposition.' (27 September, 11 October 1840.) Notwithstanding the virtues of representative government, he observed (16 August 1840),

One disadvantage, certainly, is the participation of the ill-informed and inflammable mass in intricate questions of foreign policy, of which the people are always for cutting the Gordian knots with the sword....The French are...a people young to freedom, and so proud to possess and to use it, that they must meddle and mix up their national spirit with everything. The English have left the Eastern question to the Government. The French people have taken their policy with regard to the East into their own hands, and, without listening to, or taking count of, any contrary arguments or expediency, have driven King, Minister, and a Chamber into a direct collision with all Europe.

But both he and his paper found the Tories' readiness to support Palmerston's policy disquieting, and worried that a war could strengthen the right at home (9 August, 18 October 1840). By the end of the crisis the Examiner was warning that Syria was not worth a war, and hoping that the mass of the French people would push for peace (11, October 1840).

Palmerston took a sunnier view of French society. 'The newspapers and war party have had their day,' he wrote toward the end of August in a Kantian vein (Bulwer, 1870$74,2: 320)$, 'now will come the turn of those who have been injured by these manoeuvres, and of those who would be ruined by actual war; and these people will probably now make their cries heard, though in a less noisy manner.' When Palmerston learned of the debates within the French cabinet, far from endorsing concessions, he argued it was safe 
to hold firm (Walpole, 1889, 1:356-57). The Tory leader Lord Aberdeen made a similar argument. The French people and Louis-Philippe, Aberdeen argued, would never allow the government to start a war against the rest of Europe for Mehemet Ali's sake (Parry, 1938-39, 1:144, 150-51).

In a similar fashion, expectations of British liberal solidarity may have encouraged France to stonewall in the first half of 1840. Thiers' and Rémusat's belief that the July convention was unpopular led them to think that a hard line could extract concessions (Rémusat, 1958-67, 450), though sometimes Thiers doubted that the British would back down. British liberals' hostility to alignment with the Eastern powers fed hopes of dividing the alliance should Russia intervene in the Ottoman empire (Barante, 1890-1901, 6:468; Charles-Roux, 1951, 121-22, 180). Thus the belief that the other society desired peace encouraged officials on both sides to hang tough, and for most of the crisis Palmerston imposed his preferences on a reluctant Cabinet (Bell, 1936, 1:305). '[W]ith the support of...Melbourne,' Layne $(1997,89)$ observes, 'Palmerston...carried through his policy to...the humiliation of France.'

\section{The October dénouement: structural constraints kick in}

Or did he? Pure structural-institutional theories of democratic peace hold that democracies will not fear sudden attack by their counterparts. But both realism and Owen's theory suggest that the key to a peaceful outcome can be the fear of war. Layne $(1997,96)$ describes Thiers' dismissal as a capitulation to superior force. Owen holds that so long as war does not seem imminent, societies may give illiberal leaders free rein. But as they as come to fear war against other liberals, they rally to restrain them. In both Britain and France, doves overpowered the hawks in October and forced them to make concessions. But while some of the British acted in the spirit of liberal solidarity, the French gave in for fear of defeat.

Certainly French policy makers considered themselves outmatched. LouisPhilippe warned against provoking 'a struggle of one against four,' and softliners in the cabinet warned that France was unprepared. Even Thiers admitted in the end that the army was not yet ready to take on the rest of Europe. Yet he claimed to be willing to fight if he 
had to (Charles-Roux, 1951, 178, 231; Thureau-Dangin, 1884-92, 4:274, 327-30); at any rate he was prepared to run the risk. The king talked tough at first not because he thought he could win a war, but because he thought he could avoid it. Thiers also hoped to scare the other powers into concessions. He and the rest of the cabinet hoped that standing firm would lead to a peaceful settlement favourable to France (Allison, 1926, 286; Guizot, 1858-67, 5:362, 383; Thureau-Dangin, 1884-92, 4:238-43). At the same time, Thiers did not rule out the possibility of war (Dosne, 1928, 1:204), nor, according to Rémusat (195867, 3:450, 477-78), did other cabinet members. J.P.T. Bury and R.P. Tombs (1986, 77-78) leave open the question of whether Thiers would have fought in the end, while noting that much of his inner circle thought he was prepared to do so. Though he and his colleagues expected it would be left to France to strike the first blow, he was willing to play a Schellingian game of brinksmanship (Webster, 1951, 2:707). Accidents could always bring about a war, he wrote in late August to his ambassador in St Petersburg: 'people can get carried away; some British and French boats can quarrel [s'insulter] in harbour; the Viceroy can do something rash.' (Barante, 1890-1901, 6:486.) But as the king began to fear that war might really erupt, he sought to curb Thiers, and eventually forced him out (Thureau-Dangin, 1884-92, 4:329).

In Britain, among the hardliners, Palmerston, the most important, was also the most confident. For most of the crisis, he doubted that France would dare fight the allies, though he acknowledged it could happen (Bell, 1936, 303, 311; Webster, 1951, 2:694, 699, 717-18n2). But British softliners grew increasingly alarmed. While the Whig Globe and Morning Chronicle continued to back Palmerston, Lords Clarendon, Holland and Russell came to fear war unless London compromised, and even Melbourne grew seriously worried (Melbourne, 1889, 484; Russell, 1925, 1:17, 21, 27; Scherer, 1999, 12025; Ziegler, 1976, 322-25). By October the doves were able to force Palmerston into concessions.

The moderation of Thiers' 8 October note made a good impression on the Cabinet, which, overruling Palmerston, decided that the foreign secretary should respond in the same tone. Palmerston, as usual, sought to wiggle out of this commitment, but 
under pressure from the cabinet and the queen he told the French that Britain would work for Mehemet Ali's re-instatement (Bourne, 1982, 609-11). Adolf Hasenclever (1914, 219) claims that Britain's conciliatory reaction to Thiers' note strengthened doves in the French government, leading to the prime minister's ouster, though he cites no evidence. If Louis-Philippe forced Thiers out in the expectation that London would reciprocate French concessions (Bury and Tombs, 1986, 76; Thureau-Dangin, 1884-92, 4:341-42), British overtures probably influenced his decision. ${ }^{3}$

It is tempting to conclude that by October we see liberals rallying to restrain belligerent leaders, as Owen's theory predicts. Yet while some members of the British cabinet appear to have felt a sense of liberal solidarity with France (or against Russia), such considerations played little or no role for the French. Conservatives turned against Thiers' policy because they feared domestic unrest (Tudesq, 1964, 1:519-20). When the army and navy ministers argued against war in early October, they cited not Britain's liberal political regime, but France's military unpreparedness (Dosne, 1928, 1:199; Thureau-Dangin, 1884-92, 327-28). 'We did not want war,' Rémusat (1958-67, 3:451) later recalled, 'we did not aim at it, and among a thousand reasons, one was decisive: France was not ready, and could not be for eight to nine months.' Louis-Philippe argued that the public would not endure a long war (Dosne, 1928, 1:215; Hasenclever, 1914, 227). Though the shift in public opinion emboldened him to dismiss Thiers, the king's hand did not have to be forced. Fear of a bloody defeat in battle induced him to capitulate.

\section{Conclusion}

Liberal solidarity did play some role in Britain. Liberals in and out of government regretted the decision to abandon France for autocratic Russia, and for this among other reasons, as they began to fear war, they pressed Palmerston to make concessions. The foreign secretary dodged these demands until October, but then the cabinet forced him to send a conciliatory statement and tell Paris that Britain would work for Mehemet Ali's reinstatement. These overtures may have encouraged LouisPhilippe to wind the crisis down. Yet considerations of liberal solidarity played no discernible role in French debates. Not only were such considerations absent from 
government discussions, but public pressure, far from restraining officials, drove them on. While public opinion shifted in favour of peace by October, this seems to have been due to Mehemet Ali's defeat in Syria, domestic turmoil and an assassination attempt on the king, not revived feelings of liberal solidarity (Guyot, 1926, 209-10; Thureau-Dangin, 1884-92, 4:338-45). Though Louis-Philippe may have hoped Britain would reciprocate concessions, dread of defeat was the main reason he capitulated.

This crisis also shows liberal leaders threatening each other. Palmerston, it should be noted, made deterrent rather than compellent threats (cf. Schelling, 1966, 7071), as in the statement Layne quotes: '[I]f France throws down the gauntlet we shall not refuse to pick it up; and...if she begins a war, she will to a certainty lose her ships, colonies, and commerce before she sees the end of it...her army of Algiers will cease to give her anxiety, and... Mehemet Ali will just be chucked into the Nile.' (Bulwer, 1870-74, 2:328.) Blunt words, to be sure, but 'If you take my purse, I'll knock your block off' is more consistent with friendly relations than 'Your money or your life!' Thiers' threats were vague; his note of 8 October was careful not to draw a line in the sand that the British might actually cross (Bury and Tombs, 1986, 75; Webster, 1951, 2:707). Melbourne's 20 October ultimatum, on the other hand, appears to have warned of war if France did not back down. In reality, it is unlikely that French defiance would have meant 'in a word, War, Sir.' Raymond Guyot $(1926,211)$ even argues that if Thiers had not sent his conciliatory note of 8 October, Palmerston would have had to offer a better deal or resign. Nevertheless, Melbourne-who saw France as liberal — made the threat.

Not only do we see liberal leaders threatening each other, we also see them risking war in the pursuit of bargaining advantage. Palmerston was confident throughout the crisis that France would not fight. He could thus take a hard line without, in his eyes, much chance of conflict. Yet Thiers' admiration for British institutions did not stop him from risking war. His brinksmanship involved a Schellingian 'threat that leave something to chance,' in which events might escape control. Thiers' actions are not consistent with democratic peace theory, but neither do they vindicate Layne's realist 
explanation, since the prime minister saw the balance of power as stacked against him. Just as Cold War leaders 'went to the brink' of Armageddon, Thiers gambled on a war he clearly did not want.

Perceptions that the other side wanted peace, far from ending the crisis, encouraged hawks on both sides to draw it out. Aberdeen, and Palmerston, who explicitly cited the peace-loving character of the French people, were both hardliners. Similarly, French officials' knowledge of divisions and Francophile sympathies within Britain stiffened their backs. Only at the end of the crisis do British concessions appear to have evoked a French willingness to meet them (more) than half way. Democratic peace theorists have tended to assume that expectations of co-operation and compromise will prompt reciprocal restraint. This ignores the strategic incentives that democratic leaders have to hold out for better terms.

All this should be entered on the minus side of cultural normative theory's ledger. Still, it is important to bear in mind that no French cabinet members really wanted war, nor is it clear that most deputies favoured it by October. The French left did want war, but much of it did not subscribe to liberal principles, and it did not perceive Britain as a fellow democracy. In the National's view (13 August 1840), Britain had an 'aristocratic organisation in which the children of the same country are separated by the same distances that still exist today between the whites and the blacks....Eh bien!...revolutionary France will aid the English people like all the others.' The French left's perceptions of Britain bear a striking resemblance to those of Jacksonian Democrats (Owen, 1997, 102), and in both cases, as Owen's theory predicts, liberal solidarity failed to function.

Weart is right that aristocratic and democratic republics can come into conflict, but what a democracy looks like depends on the historical context. People often define democracy not just according to the formal criteria favoured by US social scientists, but also by both the broader social structures that shape power relationships (who really governs?) and by outcomes. For British and French radicals, democracy meant rule by the people; for conservatives, it meant the rule of the mob. Both agreed that France was more 
democratic, even though the British monarch's powers were far more limited, and British suffrage was at least four times as large. For some Tories and even Whigs, France was a sea of passions with only the king's finger in the dike. Louis-Philippe 'took a more direct part in the Government than in strictness belonged to the functions of a constitutional King', observed the Morning Chronicle (19 October 1840), but

much may be said in his favour from the great difficulty in a country like France--convulsed by a succession of revolutions--of establishing an approximation even to the fixed habits which in this country have been derived from the predominance for a century and a half of a powerful aristocracy, or rather oligarchy.

The three years' longevity sometimes specified for a democracy to be considered consolidated may not be enough if the state is racked with ongoing unrest.

All this is not to say anything goes, or that states re-define their fellows as illiberal whenever they get into a quarrel (cf. Oren, 1995). History shapes perceptions of regime type, and in 1840 old enmity mattered, just as during the Franco-German crisis over the Ruhr (Owen, 1994, 96; Weart, 1998, 171). For many Frenchmen, France was the motherland of the Revolution and the standard-bearer of human progress, stymied at Waterloo by the Duke of Wellington (Darriulat, 2001, 19, 91). British Whigs welcomed France's revolution of 1830 , but many must have wondered if the tiger had really changed his stripes. Yet for the most part, perceptions on both sides during the 1840 crisis remained quite stable. French conservatives did not turn against Britain —or if they did, they soon thought twice - nor did English radicals turn against France.

Conceptions of democracy vary historically more than most theorists have assumed. Democratic peace may prevail not among states with a timeless set of characteristics, but among those sharing and subscribing to a historically specific, intersubjective version of liberalism (cf. Elman 1997, 52-53; Peceny, 1997, 421). This does not mean that cultural-normative theory is false, or that our criteria for identifying liberal states should be entirely subjective. The logic of the theory implies that the separate peace should exist only among people objectively internalising norms of compromise and self-determination. Moreover, historical conceptions of liberalism are not unrelated to our own, and this may explain why states we consider liberal today have 
rarely if ever fought. Still, criteria vary across time and place, and this, along with the hostility between oligarchic and democratic liberals, probably accounts for some exceptions or 'near misses.' We may find that no two liberal democracies have ever gone to war with each other, but democracies defined by their criteria—not ours.

\begin{abstract}
Notes
${ }^{1}$ The author acknowledges Ewan Harrison, Christopher Layne, John M. Owen IV, Steven Rendall and an anonymous referee for International Politics.

${ }^{2}$ On structural-institutional theories of democratic peace, see Russett et al., 1993, 38-40. Case-studies involving Britain are poorly suited to testing their claim that democracy mitigates incentives for preemption, since the English Channel should in any case have mitigated fears of surprise attack.

'I I have received a letter,' Louis-Philippe wrote to Thiers on 19 October, 'from my daughter the Queen of the Belgians... who writes me on behalf of the King, who does not have the time. The content appeared to me important enough to have a copy made for you.... This appears to me [unclear word-probably 'satisfaisant'], and I believe it essential to follow this advice.' The queen's letter, in turn, stated that Britain was on the point of making a significant overture: 'This is a first step toward conciliation, which should lead to others, if one takes note of it, and if one starts from this basis to draw together and to reach a mutual understanding, and it would be very wrong to consider it an escape route [échappatoire]. Going back on the deposition of Mehemet Ali is already an important concession for England, where many people wanted that deposition, and if one looks on this first concession as a first victory, one can make deft use of it to obtain more little by little.' Louis-Philippe to Thiers and copy of the Queen of the Belgians to Louis-Philippe, 19 October 1840, Bibliothèque Nationale, Paris, nouvelles acquisitions françaises, 20611; cf. Allison, 1926, 287. For the date of Melbourne's letter, see Bourne, 1982, 611.
\end{abstract}

\title{
References
}

Allison, J.M.S. (1926) Thiers and the French Monarchy, London, Constable.

Barante, A.G.P.B. (1890-1901) Souvenirs du baron de Barante de l'Académie française, 1782-1866, ed. C.A.P.F.B. de Barante, Paris, Calmann Lévy.

Bartlett, C.J. (1963) Great Britain and Sea Power: 1815-1853, Oxford, Clarendon Press.

Bell, H.C.F. (1936) Lord Palmerston, London: Longmans, Green.

Bourne, K. (1982) Palmerston: The Early Years, 1784-1841, London: Allen Lane.

Bulwer, H.L.(1870-74) The Life of Henry John Temple, Viscount Palmerston; with Selections from his Diaries and Correspondence, London: Richard Bentley.

Bury, J.P.T. and Tombs, R.P. (1986) Thiers 1797-1877: A Political Life, London: Allen and Unwin.

Charles-Roux, F. (1951), Thiers et Méhémet Ali, Paris: Plon.

Chevallier, J.-J. (1958) Histoire des institutions politiques de la France moderne (1789-1945), Paris: Dalloz. 
Collingham, H.A.C. (1988) The July Monarchy: A Political History of France, 18301848, London: Longman.

Correspondence Relative to the Affairs of the Levant (1841), London: T. R. Harrison.

Darriulat, P. (2001), Les patriotes: la gauche républicaine et la nation, 1830-1870, Paris: Seuil.

Dosne, E.S.M. (1928), Mémoires de Madame Dosne, l'Égérie de M. Thiers, ed. H. Malo, Paris: Plon.

Elman, M.F. (1997) 'The Need for a Qualitative Test of the Democratic Peace Theory' in M.F. Elman (ed.) Paths to Peace: Is Democracy the Answer? Cambridge, USA: MIT Press.

Guichen, E. (1921) La crise d'Orient de 1839 à 1841 et l'Europe, Paris: Émile-Paul.

Guizot, F. (1858-67), Mémoires pour servir à l'histoire de mon temps, Paris: Michel Lévy.

Guyot, R. (1926) La première entente cordiale, Paris: F. Rieder.

Hall, J. (1912) England and the Orleans Monarchy, London: Smith, Elder.

Hasenclever, A. (1914), Die orientalische Frage in den Jahren 1838-1841. Ursprung des Meerengen Vertrages vom 13. Juli 1841, Leipzig: K.F. Koehler.

Jennings, J.R. (1986) 'Conceptions of England and its constitution in nineteenthcentury French political thought', Historical Journal 29(1): 65-85.

Johnson, A.H. (1924) The Letters of Charles Greville and Henry Reeve, 1836-1865, London: T. Fisher Unwin.

Layne, C. (1994) 'Kant or Cant: The Myth of the Democratic Peace', International Security 19(2): 5-49.

Layne, C. (1997) 'Lord Palmerston and the Triumph of Realism: Anglo-French Relations, 1830-48' in M.F. Elman (ed.) Paths to Peace: Is Democracy the Answer? Cambridge, USA: MIT Press.

Macaulay, T.B. (1976) The Letters of Thomas Babington Macaulay, ed. T. Pinney, Cambridge, UK: Cambridge University Press.

Melbourne, W.L. (1889) Lord Melbourne's Papers, ed. L.C. Sanders, London: Longmans, Green.

Metskas, A.K. (2002) 'The Benefit of the Doubt: Attribution Theory as an Explanation for the Democratic Peace', BA thesis, Brown University.

Mitchell, L. (1980) Holland House, London: Duckworth.

Mitchell, L.G. (1997) Lord Melbourne, 1779-1848, Oxford: Oxford University Press.

Oren, I. (1995) 'The Subjectivity of the "Democratic" Peace: Changing U.S.

Perceptions of Imperial Germany', International Security 20(2): 147-84. 
Owen, J.M. (1994) 'How Liberalism Produces Democratic Peace', International Security 19(2): 87-125.

Owen, J.M., IV. (1997) Liberal Peace, Liberal War: American Politics and International Security, Ithaca: Cornell University Press.

Parry, E.J. (1938-39), ed., The Correspondence of Lord Aberdeen and Princess Lieven 1832-1854, London: Offices of the Royal Historical Society.

Peceny, M. (1997) 'A Constructivist Interpretation of the Liberal Peace: The Ambiguous Case of the Spanish-American War', Journal of Peace Research 34(4): 415-30.

Raikes, T. (1858), A portion of the journal kept by Thomas Raikes, Esq. from 1831 to 1847, London: Longman, Brown, Green, Longmans and Roberts.

Raikes T. (1861), Private Correspondence of Thomas Raikes with the Duke of Wellington and other Distinguished Contemporaries, ed. H. Raikes, London: Richard Bentley.

Ray, J.L. (1995) Democracy and International Conflict: An Evaluation of the Democratic Peace Proposition, Columbia: University of South Carolina Press.

Reeve, H. (1898) Memoirs of the Life and Correspondence of Henry Reeve, C.B., D.C.L., ed. J.K. Laughton, London: Longmans, Green.

Rémusat, C. (1958-67), Mémoires de ma vie, ed. C.H. Pouthas, Paris: Plon.

Risse-Kappen, T. (1995) 'Democratic Peace-Warlike Democracies? A Social Constructivist Interpretation of the Liberal Argument', European Journal of International Relations 1(4): 491-517.

Rubinstein, W.D. (1998), Britain's Century: A Political and Social History 18151905, London: Arnold.

Russell, J. (1925), The Later Correspondence of Lord John Russell 1840-1878, ed. G.P. Gooch, London: Longmans, Green.

Russett, B. et al. (1993) Grasping the Democratic Peace: Principles for a Post-Cold War World, Princeton: Princeton University Press.

Russett, B. and Oneal, J.R. (2001) Triangulating Peace: Democracy, Interdependence, and International Organizations, New York: W.W. Norton.

Schelling, T.C. (1966) Arms and Influence, New Haven: Yale University Press.

Scherer, P. (1999), Lord John Russell: A Biography, Selinsgrove: Susquehanna University Press.

Soltau, R.H. (1931; reprinted 1959), French Political Thought in the $19^{\text {th }}$ Century, New York: Russell and Russell.

Thureau-Dangin, P. (1884-92) Histoire de la Monarchie de Juillet, Paris: E. Plon, Nourrit. 
Tudesq, A.-J. (1964) Les grands notables en France (1840-1849): étude historique d'une psychologie sociale, Paris: Presses Universitaires de France.

Victoria, Queen of Great Britain (1907) The Letters of Queen Victoria. A Selection from Her Majesty's Correspondence Between the Years 1837 and 1861, ed. A.C. Benson and R.B.B. Esher, London: John Murray.

Walpole, S. (1889) The Life of Lord John Russell, London: Longmans, Green.

Weart, S.R. (1998) Never at War: Why Democracies Will Not Fight One Another, New Haven: Yale University Press.

Webster, C. (1951) The Foreign Policy of Palmerston 1830-1841, London: G. Bell.

Zeldin, T. (1959) 'English ideals in French politics during the nineteenth century', Historical Journal 2(1): 40-58.

Ziegler, P. (1976) Melbourne: A Biography of William Lamb 2d Viscount Melbourne, London: Collins. 